\title{
EXERGY ANALYSIS OF PROPANE-FUELLED VALVELESS PULSED COMBUSTOR
}

\author{
OLUMUYIWA A. OGUNWALE ${ }^{1}$, O.T. POPOOLA ${ }^{2} \&$ O.O. DAODU ${ }^{3}$ \\ ${ }^{1,3}$ Department of Physical Planning and Development, Landmark University, Omu-Aran, Nigeria \\ ${ }^{2}$ Department of Mechanical Engineering, University of Ilorin, Ilorin, Nigeria
}

\begin{abstract}
This paper presents the thermodynamic study of valveless pulsed combustor when fuelled with propane gas. Methodology for evaluating the exergy performance was developed using the mass, energy and exergy balance between the input and output material streams in the combustor at ambient temperature. At three different consumption rates of fuel and air, the highest exergy efficiency of $65.61 \%$ was obtained at the combustion chamber at $0.0013 \mathrm{~kg} / \mathrm{s}$ of propane gas neglecting heat losses at the combustor wall. Heat transfer that occurs at high temperature was considered to be responsible for the reduction in the exergy efficiency of the combustor at an increase in the flow rate of propane gas.

KEYWORDS: Combustor, Efficiency, Exergy, Gas \& Temperature
\end{abstract}

Received: Dec 01, 2019; Accepted: Dec 19, 2019; Published: Mar 17, 2020; Paper Id.: IJMPERDAPR202055

\section{INTRODUCTION}

Valveless pulsed combustor is a typical open system combustion device having characteristics of the non-adiabatic combustion process. As a propulsion system that operates on the Lenoir cycle, it is simple in construction, lightweight with low cost and has no compression process. This device is known to be capable of operating statically [1].

The valveless combustion device is divided into three main compartments namely; the inlet, combustion chamber and the tailpipe. When the mixture of fuel and air undergoes combustion in the combustion chamber of the pulsejet, the process produces a great quantity of hot gases in a quick manner like an explosion [2].

However, the lack of compression process has negatively affects the efficiency obtained in the system. The configuration of the valveless pulsejet not withstanding its overall low thermal efficiency that has made it a suitable candidate for miniaturization due to extreme simple design as it is advantageous for building smaller propulsion and heating devices [3].

Since it is known that exergy loss always accompanies the combustion of fuel in the system such as valveless combustor due to generation of entropy, it has become highly essential to evaluate the magnitude of the loss to estimate the maximum theoretical available work that is obtainable from the combustor for practical applications.

Exergy analysis is considered a viable process for evaluating the thermal performance of the valveless pulsejet. Exergy is defined [4] as the work obtainable from an amount of energy at an ideal conditions (applying reversible processes), with the environment that only serving as a reservoir of heat and matter. The analysis is aimed at evaluating the combustion process in valveless pulsed combustor in terms of exergy performance and this 
evaluation can help in minimization of losses or optimization of driving forces.

[5] performed an exergy analysis of an adiabatic combustor connected to the annealing chamber of a furnace to understand the concept of its energy and exergy utilization. When light diesel having mass flow rate of $0.011 \mathrm{~kg} / \mathrm{s}$ was introduced as fuel in the combustor and air with flow rate of $0.165 \mathrm{~kg} / \mathrm{s}$ at the ambient conditions of temperature and pressure of $25^{\circ} \mathrm{C}$ and $100 \mathrm{kPa}$ respectively, the result of the energy obtained from combustor after combustion was found to be $556.3 \mathrm{~kJ} / \mathrm{s}$ while the exergy destruction rate is $215.1 \mathrm{~kJ} / \mathrm{s}$ and exergy efficiency is $47.1 \%$.

Similar analysis had also been carried out by [6] with a focus on exergy analysis of an adiabatic combustor which forms an integral part of an industrial boiler. When the surrounding temperature and pressure were $25^{\circ} \mathrm{C}$ and $100 \mathrm{kPa}$ respectively, energy used by the combustor when fired with $0.275 \mathrm{~kg} / \mathrm{s}$ of methane gas and $4.125 \mathrm{~kg} / \mathrm{s}$ of air was $15,417.8$ $\mathrm{kJ} / \mathrm{s}$.

The exergy destruction rate as obtained for the combustor was $6,660 \mathrm{~kJ} / \mathrm{s}$, while the value of its exergy efficiency was $45.18 \%$.

In this study, exergy analysis of valveless pulsed combustor that was fuelled with propane gas is conducted using the principle of thermodynamic laws. The exergy method uses the principles of first and second laws of thermodynamics [7]. However, this study will be useful to determine the amount of energy that is available after the combustion of propane fuel and to state the exergy efficiency of the valveless pulsed combustor.

\section{METHODOLOGY}

This section highlights the properties of the inlet streams and the mathematical relations for performing exergy and energy analysis of a system.

\section{The Reference Environment}

Exergy is usually evaluated with respect to the reference environment conditions [6]. Considering the ambient conditions under which the experiment was performed by [8], the surrounding pressure $P_{0}$ and temperature $T_{0}$ used in this analysis are $88.253 \mathrm{kPa}$ and $289 \mathrm{~K}$ respectively.

\section{Specifications of the Input Streams}

The input streams in the combustor are propane gas and air. The enthalpy of air at ambient temperature is $289.16 \mathrm{~kJ} / \mathrm{kg}$ while the higher heating value (HHV) of propane and its enthalpy of formation are $50,330 \mathrm{~kJ} / \mathrm{kg}$ and $-103,850 \mathrm{~kJ} / \mathrm{kmol}$ respectively.

Meanwhile, the mass flow rates of air and fuel as considered in the experiment are presented in table 1.

Table 1: Mass Flow Rate of Input Streams in Valveless Pulsed Combustor

\begin{tabular}{|c|c|}
\hline$\dot{m}_{a}(\mathrm{~kg} / \mathrm{s})$ & $\dot{m}_{f}(\mathbf{k g} / \mathbf{s})$ \\
\hline 0.032 & 0.0013 \\
\hline 0.040 & 0.0020 \\
\hline 0.046 & 0.0031 \\
\hline
\end{tabular}

However, the analytical method used for determining the available energy and exergy efficiency of the combustor is described as follows. 


\section{Energy and Exergy Evaluation of the Combustor}

Thermodynamics' first law analysis is basically an energy-based approach in any thermal system [9]. The valveless pulsed combustor as a typical thermal system is divided into three compartments namely the inlet, combustion chamber, and the tailpipe. The mass flow rate and temperature data used for the analysis were obtained from the experimental work of [8]. This data is presented in table 2 .

Table 2: Mass Flow Rates of Air, Fuel, and Temperature in Combustor of Propane-Fuelled

\begin{tabular}{|c|c|c|c|c|}
\hline \multicolumn{4}{|c|}{} & \multicolumn{3}{|c|}{ Combustor } \\
\hline$\dot{m}_{f}(\mathrm{~kg} / \mathrm{s})$ & $\dot{m}_{a}(\mathbf{k g} / \mathbf{s})$ & Inlet (Port1) & Combustion Chamber (Port3 & Tailpipe (Port6) \\
\hline 0.0013 & 0.032 & 627 & 1319 & 940 \\
\hline 0.0020 & 0.040 & 66 & 1482 & 963 \\
\hline 0.0031 & 0.046 & 731 & 1617 & 939 \\
\hline
\end{tabular}

It has been established empirically that the composition of the products after a chemical reaction is dependent upon the composition of the reactant constituent's i.e (fuel and air). If the reactant components contain sufficient oxygen, there would be complete oxidation of hydrocarbon fuel.

Such a process, results in the conversion of carbon in the fuel to carbon dioxide $\left(\mathrm{CO}_{2}\right)$ and hydrogen to water $\left(\mathrm{H}_{2} \mathrm{O}\right)[10]$.

For this analysis, fuel combustion has been assumed to be complete and a stoichiometric amount of air was used.

The chemical reaction for the complete combustion of propane gas is described as;

$$
\mathrm{C}_{3} \mathrm{H}_{8}+5\left(\mathrm{O}_{2}+3.76 \mathrm{~N}_{2}\right) \rightarrow 3 \mathrm{CO}_{2}+4 \mathrm{H}_{2} \mathrm{O}+18.8 \mathrm{~N}_{2}
$$

\section{Thermodynamics First Law Analysis of Valveless Pulsed Combustor}

The combustor considered in this experiment was a typical open thermodynamic system in which enthalpy of combustion was released after the burning of fuel. However, it is assumed that it performs no work, hence, work W equals zero. The total energies of the incoming and outgoing streams are assumed to be equal and constant while the potential and kinetic energies of the gaseous fluid streams are also assumed to be negligible.

The heat released from the conversion of the chemical energy of propane gas to heat energy during the combustion is meant to perform industrial applications such as the melting of metal in a furnace and for thrust generation. It is, therefore, necessary to evaluate the heat that is derivable from the combustion process [11].

From the expression of the first law of thermodynamics, [12] defined the energy balance for an open thermodynamics system at a steady state conditions as;

$$
\sum_{i} \dot{m} h-\sum_{j} \dot{m} h+\sum_{s} \dot{Q}-\dot{W}=0
$$

The expression of Equation (2) can be further expanded and rearranged to become; 


$$
\sum_{i} m_{i} h_{i}+\sum_{s} \dot{Q}=\sum_{j} m_{j} h_{j}+\dot{W}
$$

Where, the LHS expression represents the inlet streams, while, RHS expression denotes the outlet streams from the combustor. Meanwhile, the conservation of energy principle requires the total energies of the inlet stream in the LHS that equals the total energies of the outlet stream in RHS and work $\dot{W}$ is assumed to be zero since the hot flue gas does not do work. The schematic of energy balance in valveless pulsed combustor is presented in Figure 1.

From Equation (3), therefore, $E_{i n}=\dot{m}_{a} h_{a}+\dot{m}_{f} h_{f}+\dot{Q}$

Where $Q$ is the enthalpy of combustion which is represented as;

$$
\dot{Q}=\sum_{p} n_{p}\left(h_{f}\right)-\sum_{r} n_{r}\left(h_{f}\right)
$$

Where, $n_{p}$ and $n_{r}$ symbolizes the number of moles of product and reactant respectively, while $h_{f}$ denotes the enthalpy of formation.

Since the fuel under consideration is propane gas, hence $Q$ becomes;

$$
\dot{Q}=\left(n_{\mathrm{CO}_{2}} h_{\mathrm{CO}_{2}}+n_{\mathrm{H}_{2} \mathrm{O}} h_{\mathrm{H}_{2} \mathrm{O}}-n_{c_{3} \mathrm{H}_{8}} h_{c_{3} \mathrm{H}_{8}}\right)
$$

Where, the enthalpies formation of carbondioxide, water, and propane gas is determined from the standard thermodynamics table while the moles are determined from the balanced equation of the reaction.

Therefore, from Equation (4), the energy available after the combustion of propane gas in the combustor can be determined simply by taking the specific enthalpy of fuel as the higher heating value.

\section{Thermodynamics Second Law Analysis on Combustor}

Exergy is a property that represents a better measure of the work which is derivable from a system by taking into careful consideration the potential losses that was resulted from the interaction between the system and its surroundings especially as the system advances towards a specific final state of equilibrium with immediate surroundings.

Therefore, considering the assumptions that have been stated in the previous section, such as, the determination of physical, chemical and thermal exergies is crucial for defining the energy available for useful work by the combustor.

\section{The Specific Chemical Exergy of Air}

The specific chemical exergy of air is expressed by [7] in Equation (7) as;

$$
\mathcal{E}_{a}^{c h}=\frac{e_{x(a i r)}^{c h}}{M}
$$

Where, M represents the molar mass of air which has the value $M_{\text {air }}=28.96 \mathrm{~kg} / \mathrm{kmol}[13]$. 
$e_{x(\text { air })}^{c h}$ is the molar chemical exergy of the atmospheric air and is determined using Equation (8) and from the values of moles fraction of elements in Tables 3 .

$$
e_{x(\text { air })}^{c h}=\sum\left(n_{i} e_{x i}^{c h}\right)_{a i r}
$$

\begin{tabular}{|c|c|}
\hline \multicolumn{2}{|c|}{ Table 3: Properties of Atmospheric Air Constituents } \\
\hline Air Constituents & Mole Fraction \\
\hline $\mathrm{N}_{2}$ & 0.7565 \\
\hline $\mathrm{O}_{2}$ & 0.2035 \\
\hline $\mathrm{H}_{2} \mathrm{O}$ & 0.0303 \\
\hline $\mathrm{Ar}$ & 0.0091 \\
\hline $\mathrm{CO}_{2}$ & 0.0003 \\
\hline $\mathrm{H}_{2}$ & 0.0001 \\
\hline
\end{tabular}

Source: [14]

\section{The Specific Chemical Exergy of Fuel}

The specific chemical exergy of fuel is expressed by [7] as;

$$
\mathcal{E}_{f}^{c h}=\frac{e_{x(f u e l)}^{c h}}{M}
$$

Where, $e_{x(f u e l)}^{c h}$ denotes the chemical exergy of fuel and $\mathrm{M}$ is the molar mass of the chemical substance in $\mathrm{kg} / \mathrm{mol}$.

However, for propane hydrocarbon fuel whose general complete combustion equation is represented in Equation (10), molar chemical exergy of reactants and products constituents is determined by [15] and expressed in Equation (11) as follows;

$$
\begin{aligned}
& C_{x \backslash} H_{y}+\left(x+\frac{y}{4}\right)\left(O_{2}+3.76 N_{2}\right) \rightarrow x C_{2}+\frac{y}{2} H_{2} O+\left(x+\frac{y}{4}\right) 3.76 N_{2} \\
& e_{x(f u e l)}^{c h}+\left(x+\frac{y}{4}\right) e_{x\left(O_{2}\right)}^{c h} \rightarrow-\Delta g+x e_{x\left(C_{2}\right)}^{c h}+\frac{y}{2} e_{x\left(H_{2} O\right)}^{c h}
\end{aligned}
$$

Where, $\mathrm{x}$ and $\mathrm{y}$ are number of moles that describes the hydrocarbon and combustion reaction.

From Equation (11), the chemical exergy of the fuel is expressed by [15] in Equation (12) as follows;

$$
e_{x(f u e l)}^{c h}=-\Delta g+\operatorname{RTIn}\left[\frac{n_{\mathrm{O}_{2}}{ }^{(x+y / 4)}}{n_{\mathrm{CO}_{2}} n_{\mathrm{H}_{2} \mathrm{O}}{ }^{y / 2}}\right]
$$

where $n_{\mathrm{O}_{2}}, n_{\mathrm{CO}_{2}}$, and $n_{\mathrm{H}_{2} \mathrm{O}}$ represents mole fractions of oxygen, carbon dioxide, and water respectively in standard environment and these values are specified in Table 4. 
Table 4: Chemical Exergies of Constituents of

Atmospheric air at a Standard Conditions, $70 \%$

Relative Humidity

\begin{tabular}{|l|c|}
\hline \multicolumn{1}{|c|}{ Components } & $\begin{array}{c}\text { Chemical Exergies } \\
\text { (kJ/kmol) }\end{array}$ \\
\hline Nitrogen, $\mathrm{N}_{2}$ & 0.6681 \\
\hline Oxygen, $\mathrm{O}_{2}$ & 3.9305 \\
\hline Carbon dioxide, $\mathrm{CO}_{2}$ & 19.610 \\
\hline Argon, $\mathrm{Ar}$ & 11.640 \\
\hline Water, $\mathrm{H}_{2} \mathrm{O}(\mathrm{g})$ & 9.474 \\
\hline Water, $\mathrm{H}_{2} \mathrm{O}(\mathrm{liq})$ & 0.8842 \\
\hline Hydrogen, $\mathrm{H}_{2}$ & 236.098 \\
\hline Carbon monoxide, $\mathrm{CO}$ & 274.87 \\
\hline Source: $[7]$ & \\
\hline
\end{tabular}

\section{Thermal Exergy}

At high combustion temperature, exergy is destroyed as a result of entropy generation and transfer of heat to the environment which acts as a cold reservoir. The thermal exergy $e x_{t h}$ associated with the heat transfer in and out of the control process is expressed by [16] as;

$$
e \dot{x}_{t h}=\sum\left(1-\frac{T_{0}}{T_{h s}}\right) \dot{Q}_{h s}
$$

Where, $T_{h s}$ denotes the temperature of heat source,

$Q_{h s}$ represents the heat transfer rate of the heat source,

$T_{0}$ is the ambient temperature.

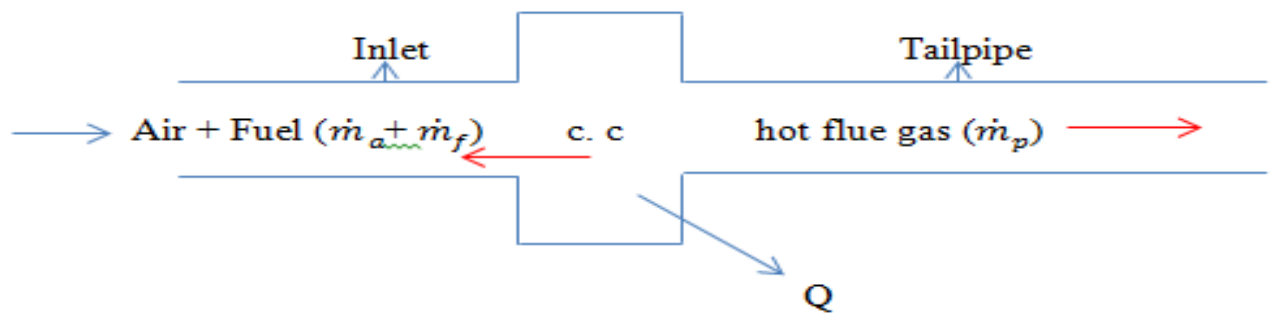

Figure 1: Schematic of Pulsed Combustion Process.

\section{Exergy Destruction}

Exergy is a thermodynamic potential that is not conserved as energy, but destroyed in the system. Exergy destruction is the measure of irreversibility which occurs as a result of entropy generation in a system.

The exergy balance for a control volume considered at a steady state, steady flow condition ignoring kinetic and potential energies change in the system is expressed by [16] as; 


$$
\sum_{i} \dot{m}_{i} h_{i}+\sum_{i} \dot{e} x_{t h}=\sum_{e} \dot{m}_{e} h_{e}+\dot{e} x^{w}+I_{c}
$$

Where, $e x_{t h}$ is the thermal (heat) exergy, $e x^{w}$ represents exergy rate at specific work, $h_{i}$ is the specific exergy of inlet stream, $h_{e}$ is specific exergy of the outlet stream, $m_{i}$ is a mass flow rates of the inlet stream, $m_{e}$ is a mass flow rate of the outlet stream from the combustor and $I_{c}$ is exergy destruction.

In Equation (14), if it is assumed that no work is done by the combustor then exergy destruction becomes;

$$
I_{c}=\sum_{i} \dot{m}_{i} h_{i}-\sum_{e} \dot{m}_{e} h_{e}+\sum_{i} \dot{e} x_{t h}
$$

\section{Exergy Efficiency}

To define the exergy efficiency of a combustion system, it is important to identify the fuel and the product of the system. The product of the combustion process and the fuel consumed during the process are used to derive the product exergy and the input exergy, respectively.

However, [17] expressed exergy efficiency to be the ratio of total product exergy to total input exergy as expressed in Equation (16).

$$
\eta_{E}=\frac{\operatorname{Pr} \text { oduct }}{\text { Input }}
$$

Considering that there is no universal definition of input and an output as stated by [17] and as further confirmed by [9] who ruled out standard set of definition for input and output in a literature, taking into cognizance the significance of thermal exergy on this open system combustion process, the appropriate exergy efficiency is given as;

$$
\eta_{E}=\frac{\dot{m}_{p}\left(h_{p}-T_{0} S_{p}\right)}{\dot{m}_{f}\left[\left(h_{f}-T_{0} S_{f}\right)+\varepsilon_{f 2}^{c h}-\varepsilon_{f 3}^{c h}\right]+\left(1-\frac{T_{0}}{T_{h s}}\right) \dot{Q}_{h s}}
$$

\section{RESULTS AND DISCUSSIONS}

\section{Available Energy in Combustor}

If the assumptions, earlier stated in section 2 are observed and the data in Table 1 is substituted into Equation (4), then the values of the energy input in the combustor is presented in figure 2 below. 


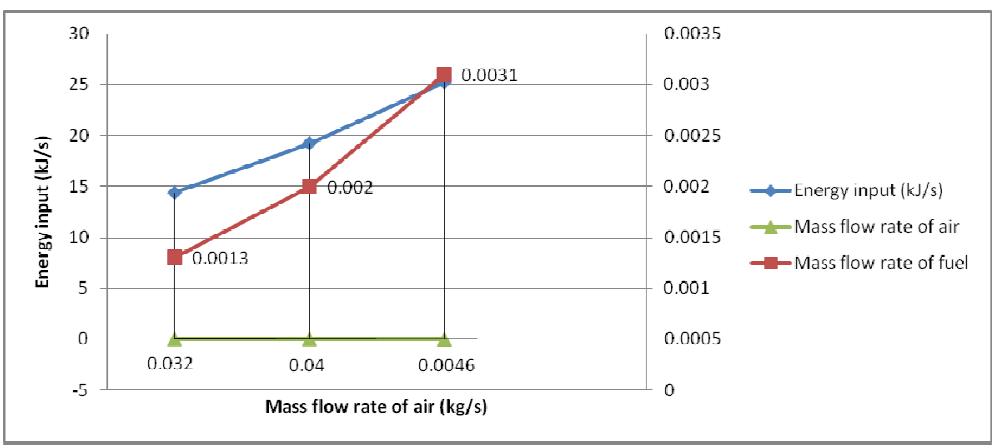

Figure 2: Energy input into Propane-Fuelled Combustor at Different Mass Flow Rates of Fuel and Air.

\section{Exergy Destruction in the Combustor}

Exergy destruction is determined from Equation (15), when it has been further expanded to become;

$$
I_{c}=\dot{m}_{a}\left[h_{a}-T_{0} S_{a}+\varepsilon_{a}^{c h}\right]+\dot{m}_{f}\left[\left(h_{f}-T_{0} S_{f}\right)+\varepsilon_{f 2}^{c h}-\varepsilon_{f 3}^{c h}\right]+\left(1-\frac{T_{0}}{T_{h s}}\right) \dot{Q}_{h s}-\dot{m}_{p}\left(h_{p}-T_{0} S_{p}\right)
$$

Taking into consideration, the available data in Table 1 and the specific enthalpies and entropies values obtained during the process, the values of exergy destruction as obtained in the combustor is presented in figure 2 below.

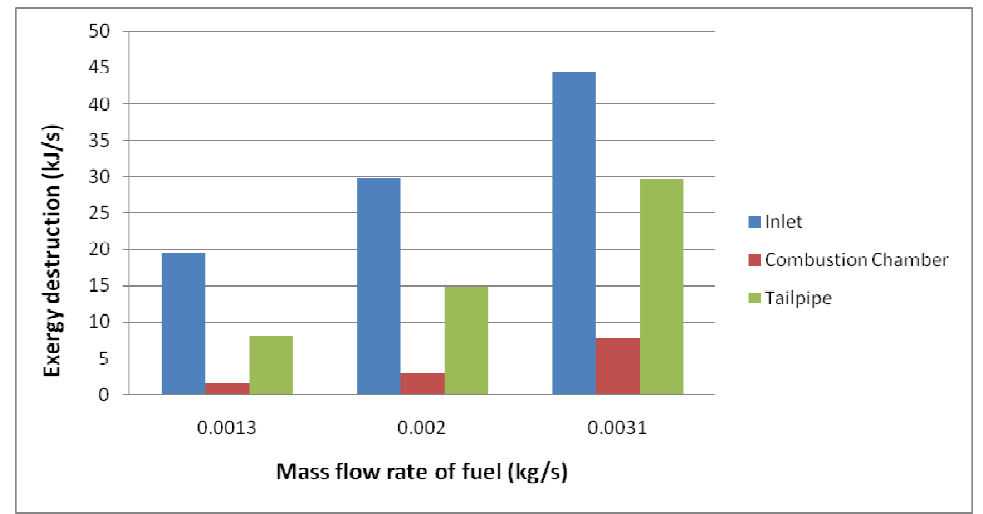

Figure 3: Exergy Destruction in Propane-Fuelled Valveless Pulsed Combustor.

\section{Exergy Efficiency of Combustor}

The exergy efficiency is determined in Equation (17). From the data available for the analysis, the computation of the exergy efficiency of the combustor is performed and the results obtained are presented in figure 4. 


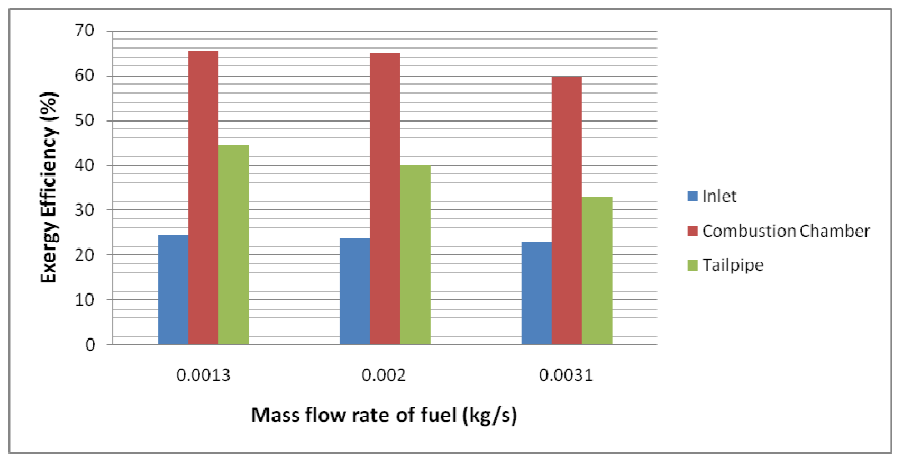

Figure 4: Exergy Efficiency of Propane-Fuelled Valveless Pulsed Combustor.

\section{DISCUSSION OF RESULTS}

Results of the exergy analysis, as obtained at the combustion chamber and as conducted in this work are compared with the results of an existing literature and presented in table 5.

Table 5: Comparison of Exergy Analysis Results at Combustion Chamber of Combustors

\begin{tabular}{|c|c|c|c|c|c|c|}
\hline $\begin{array}{l}\text { SI. } \\
\text { No. }\end{array}$ & Author & $\begin{array}{l}\text { Fuel } \\
\text { Used }\end{array}$ & Method Used & $\dot{m}_{a}(\mathbf{k g} / \mathbf{s})$ & $\dot{m}_{f}(\mathbf{k g} / \mathbf{s})$ & Results \\
\hline 1 & $\begin{array}{l}\text { (Hasanuzzaman } \\
\text { et al. 2011) }\end{array}$ & $\begin{array}{l}\text { Light } \\
\text { diesel }\end{array}$ & $\begin{array}{c}E_{i n}=\dot{m}_{a} h_{a}+\dot{m}_{f} h_{f} \\
\eta_{B}=\frac{\dot{m}_{p} \varepsilon_{p}}{\dot{m}_{f} \varepsilon_{f}}\end{array}$ & 0.165 & 0.011 & $\begin{array}{l}E_{\text {in }}= \\
556.3 \\
\mathrm{~kJ} / \mathrm{s} \\
\eta_{B}= \\
47.1 \%\end{array}$ \\
\hline \multirow{3}{*}{2} & \multirow{3}{*}{ Present Work } & \multirow{3}{*}{ Propane } & \multirow{3}{*}{$\begin{array}{c}E_{i n}=\dot{m}_{a} h_{a}+\dot{m}_{f} h_{f}+\dot{Q} \\
\eta_{B}= \\
\dot{m}_{p}\left(h_{p}-T_{0} S_{p}\right) \\
\frac{m_{f}\left[\left(h_{f}-T_{0} S_{f}\right)+\varepsilon_{f 2}^{c h}-\varepsilon_{f 3}^{c h}\right]+\left(1-\frac{T_{0}}{T_{h s}}\right) \dot{Q}_{h s}}{}\end{array}$} & 0.032 & 0.0013 & $\begin{array}{l}E_{\text {in }}= \\
14.38 \\
\mathrm{~kJ} / \mathrm{s}, \\
\eta_{B}= \\
65.61 \\
\%\end{array}$ \\
\hline & & & & 0.040 & 0.0020 & $\begin{array}{l}E_{\text {in }}= \\
19.23 \\
\mathrm{~kJ} / \mathrm{s}, \\
\eta_{B}= \\
64.81 \\
\%\end{array}$ \\
\hline & & & & 0.046 & 0.0031 & $\begin{array}{l}E_{\text {in }}= \\
25.22 \\
\mathrm{~kJ} / \mathrm{s}, \\
\eta_{B}= \\
59.62 \\
\%\end{array}$ \\
\hline
\end{tabular}

\section{CONCLUSIONS}

The following conclusions were drawn from this study; 
- In figure 2, it is obvious that the energy values available in the combustor owing to fuel combustion of fuel are $14.38 \mathrm{~kJ} / \mathrm{s}, 19.23 \mathrm{~kJ} / \mathrm{s}$ and $25.22 \mathrm{~kJ} / \mathrm{s}$ when the combustor was fired using the propane fuel at three different consumptions rates of $0.0013 \mathrm{~kg} / \mathrm{s}, 0.0020 \mathrm{~kg} / \mathrm{s}$ and $0.0031 \mathrm{~kg} / \mathrm{s}$, respectively.

- The rate of exergy destruction in the combustor increases with an increase in the consumption of fuel as depicted in figure 3.

- Exergy efficiencies obtained at the combustion chamber at three different consumption rates of propane gas of $0.0013 \mathrm{~kg} / \mathrm{s}, 0.0020 \mathrm{~kg} / \mathrm{s}$ and $0.0031 \mathrm{~kg} / \mathrm{s}$ are $65.61 \%, 64.81 \%$ and $59.62 \%$, respectively. From this result, exergy efficiency reduces as mass flow rates of propane gas and air increases during the combustion. The exergy loss that occurred can be adduced to heat transfer in the combustor and it is related to temperature difference which becomes higher at an increased fuel and air flow rates.

- The exergy efficiency obtained in this work indicates the percentage of useful work which is available or for conversion to other kinds of energy as required for a practical use of combustor such as smelting purposes; drying and for thrust generation.

- The methodological framework employed in this study, assumes heat losses at the combustor wall to be negligible; however, further research can be done by taking into consideration the effect of conductive and radiative heat on exergy performance of the valveless pulsed combustor.

\section{NOMENCLATURE}

\begin{tabular}{|c|l|}
\hline Symbol & \multicolumn{1}{|c|}{ Meaning } \\
\hline $\mathrm{C}$ & Carbon \\
\hline $\mathrm{CO}_{2}$ & Carbondioxide \\
\hline$C_{x} H_{y}$ & Hydrocarbon (fossil fuel) molecules \\
\hline $\mathrm{E}$ & Energy \\
\hline$e_{x(\text { air })}^{c h}$ & Molar chemical exergy of air \\
\hline$e_{x(f u e l)}^{c h}$ & Molar chemical exergy of fuel \\
\hline$\dot{x}_{t h}$ & Thermal (heat) exergy \\
\hline$e^{w}$ & Exergy rate at specific work \\
\hline $\mathcal{E}^{w}$ & $\begin{array}{l}\text { Specific flow exergy of materials } \\
\text { stream }\end{array}$ \\
\hline$T_{h s}$ & Temperature of the heat source \\
\hline$\varepsilon_{a}^{c h}$ & Specific physical exergy of air \\
\hline $\mathcal{E}_{f}^{c h}$ & Specific chemical exergy of fuel \\
\hline $\mathcal{E}_{f 3}^{c h}$ & $\begin{array}{l}\text { Specific chemical exergy of the } \\
\text { exhaust flue gas }\end{array}$ \\
\hline $\mathrm{H}$ & Hydrogen \\
\hline$H_{2} O$ & Water \\
\hline $\mathrm{HHV}$ & $\begin{array}{l}\text { Gross calorific value or high } \\
\text { heating value }\end{array}$ \\
\hline
\end{tabular}




\section{Subscripts and Superscripts}

\begin{tabular}{|c|l|}
\hline$I_{c}$ & Exergy destruction rate \\
\hline $\mathrm{M}$ & Molar mass of chemical substance \\
\hline$\dot{m}$ & Mass rate of substance \\
\hline $\mathrm{n}$ & Amount in moles of substance \\
\hline$N_{2}$ & Nitrogen \\
\hline$\eta_{B}$ & Exergy efficiency \\
\hline $\mathrm{O}$ & Oxygen \\
\hline $\mathrm{P}$ & Pressure \\
\hline$\dot{Q}$ & Enthalpy of combustion \\
\hline $\mathrm{R}$ & Molar gas constant \\
\hline $\mathrm{s}$ & Specific entropy \\
\hline$T_{0}$ & Reference state ambient temperature \\
\hline
\end{tabular}

\begin{tabular}{|l|l|}
\hline Symbol & \multicolumn{1}{|c|}{ Meaning } \\
\hline $\mathrm{a}$ & air \\
\hline $\mathrm{ch}$ & chemical \\
\hline $\mathrm{e}$ & outlet stream \\
\hline $\mathrm{f}$ & fuel \\
\hline $\mathrm{i}$ & inlet stream \\
\hline 0 & reference state \\
\hline $\mathrm{p}$ & hot product \\
\hline $\mathrm{r}$ & reactant \\
\hline $\mathrm{ph}$ & physical \\
\hline
\end{tabular}

\section{REFERENCES}

1. Trancossi, M, Mohammedalamin, O, Pascoa, J. \& Rodrigues, F. (2006). Thermodynamic analysis and preliminary design of the cooling system of a pulsejet for aeronautic propulsion. International Journal of Heat and Technology, 34(2), S528-S534.

2. Ogorelec, B. (2005). A historical review of valveless pulsejet designs. Zagreb, Croatia: TIS Books

3. Shashank, R.C, Rajesh, G. \&Sarviya R.M. (2013). Performance Analysis of a Pulsejet Engine. International Journal of Engineering Research and Applications, 3(4), 605-609.

4. Ertesvag, I.S. (2007). Sensitivity of the chemical exergy for atmospheric gases and gaseous fuels to variations in ambient conditions. Energy Conservation Management, 48, 1983-95

5. Hasanuzzaman, M, Saidur, R. \& Rahim, N.A. (2011). Energy, exergy and economic analysis of an annealing furnace. International Journal of the Physical Sciences, 6(6), 1257-1266.

6. Saidur, R, Ahamed, J.U. \& Masjuki, H.H. (2010). Energy, exergy and economic analysis of industrial boilers. Energy Policy, 38, 2188-97.

7. Ohijeagbon, I.O., Waheed, M.A., \& Jekayinfa, S.O. (2013). Methodology for the physical and chemical exergetic analysis of steam boilers. Energy, 39, 1-12.

8. Olorunmaiye, J.A. (1984). Numerical simulation and experimental studies of highly-loaded valveless pulsed combustor (Doctoral Dissertation).The University of Calgary, Alberta, Canada.

9. Hakan A., Karakoc T., \& Adnan M. (2014). Some exergetic measure of a JT8D Turbofan Engine. Journal of Automation and Control Engineering, 2, 110-114. 
10. Heywood, J. (1988). Internal combustion engine fundamentals. New York: McGraw Hill.

11. Seif, A.A, Bahgat, K.M, Ahmed, A.A. (2014). A study of exergy analysis for combustion in direct fired heater (Part 1), Mathematical Methods in Science and Engineering, Athens, 2014. Athens: www.inase.org

12. Mohammad, A, Farzad, K, \& Mansour, K. (2012). Comparative analysis of the performance of a dual-fuel internal combustion engine for CNG and gasoline fuels. Journal of power technologies, 4, 214-226.

13. Cengel, Y.A., \& Boles, M.A. (2004). Thermodynamics: An Engineering Approach (5 ${ }^{\text {th }}$ ed.). Chicago, USA: McGraw Hill.

14. Dincer, I. \& Rosen, M.A. (2007). Exergy: energy, environment and sustainable development (First ed.). Oxford, UK: Elsevier

15. Roger, G, \& Mayhew, Y. (1992). Engineering Thermodynamics: work and heat transfer (4 ${ }^{\text {th }}$ ed.). UK: Longman Group Limited.

16. Dincer, I. \& Rosen, M.A. (2007); Ajimotokan (2014). A study of trilateral flash cycles for low-grade waste heat recovery-topower generation (Doctoral Dissertation). Cranfield University, Cranfield, UK.

17. Modesto, M. \& Nebra, S.A (2009). Exergoeconomic analysis of the power generation system using blast furnace and coke oven gas in a Brazilian steel Mill. Applied Thermal Engineering, 29, 2127-2136 